\title{
Intervention with Fe Supplementations and IEC About Anemia Against Hemoglobin Levels in Female Teenagers in State Senior High School
}

\author{
Indah Sri Wahyuni \\ Polytechnic Karya Husada, Midwifery Diploma III Study Program, Jakarta, Indonesia \\ Corresponding author email: indahsekali03@gmail.com \\ Eka Bati Widyaningsih \\ Polytechnic Karya Husada, Midwifery Diploma III Study Program, Jakarta, Indonesia \\ Email: ekabati02@gmail.com
}

\begin{abstract}
Iron malnutrition anemia is a micronutrient problem that often occurs throughout the world. The prevalence of nutritional anemia in the teenager's age group nationally is $18.4 \%$. The government has a program to prevent anemia in adolescents, which is to provide one grain of iron supplements every week throughout the year for female teenagers at school. The administration was carried out for 16 weeks with details of once a week and for 10 days of menstruation, so that the total gave was 52 tablets. Examine the characteristics of the sample (age, family socioeconomic, pocket money, menstrual history, nutritional status, and physical activity), knowledge about anemia, attitudes, compliance, family support, and teacher support in interventions with Fe supplementation and IEC about anemia against hemoglobin levels for female teenagers in State Senior High School in the District of Pesanggrahan, South Jakarta, Indonesia. This research is a Quasi-Experimental with a sample of 126 female teenagers. The difference in the mean hemoglobin level of the intervention group before and after the intervention showed a significant difference in the average hemoglobin level between the three groups at pretest. The result of the multi regression analysis shows that the dominant variable is knowledge.
\end{abstract}

Keywords---anemia, Fe supplement, female teenagers, hemoglobin, IEC anemia.

\section{Introduction}

Iron malnutrition anemia is a micronutrient problem that often occurs throughout the world, especially in developing countries where it is estimated to occur in $30 \%$ of the world's population. Anemia is common in all age groups, especially in adolescents and pregnant women. Women have the highest risk of anemia, especially in women of childbearing age, which is about half a million. As much as $29 \%$ of women of childbearing age who are not pregnant have anemia and 38\% of pregnant women aged 15-49 years have anemia (WHO, 2011).

The purpose of giving Fe supplementation to young women is to meet the iron needs of those who will become mothers in the future. With adequate iron intake from an early age, it is hoped that the incidence of anemia in pregnant women, bleeding during childbirth, low birth weight, and short children under five can decrease. The prevalence of anemia in women aged 15 to 49 years occurs mostly in Southeast Asia, 42\%, Africa 39\%, East Mediterranean 38\%, Europe 23\%, West Pacific 20\%, and America 17\%. The prevalence of nutritional anemia in the teenager's age group (15 to 24 years) nationally is $18.4 \%$. The coverage of Fe supplementation for female teenagers in Indonesia in 2017 was 29.51\%. This has met the 2017 Strategic Plan target of 20\%. Ten provinces have not met the Strategic Plan target, one of which is DKI Jakarta, which only reached 6.11\% (Rollinson, 2011; Levy et al., 2005; Tefferi, 2003).

There are three factors behind the incidence of anemia, the first is a direct cause such as a lack of iron levels in the blood and a body condition that is infected with the disease. The second cause is indirect causes, namely low 
family attention, high activity, and inaccurate food distribution patterns in the family. The third cause is the basic cause are education, low income, low social status, and difficult geographical location to live in (Simamora et al., 2018). The impact of iron nutrition anemia on adolescents includes disrupted growth and development, fatigue, increased susceptibility to infection, reduced physical abilities, and academic abilities (Brown, 2016).

The government has a program to prevent anemia in adolescents, which is to provide one grain of iron supplements every week throughout the year (52 tablets) for young girls at school. The administration was carried out for 16 weeks with details of once a week and for 10 days of menstruation, so that the total gave was 52 tablets. (Rollinson, 2011).

\section{Material and Methods}

This study used a Quasi-Experimental research design. In this study, a pre-test and post-test control group design will be carried out to divide between the treatment and control groups (Campbell \& Stanley, 2015). The intervention was providing iron supplements and IEC about anemia through comic media. The stages of the treatment delivery method are as follows: First hemoglobin check, pre-test, IEC was given through comic media for the treatment group who received IEC with digital comic media were previously given an explanation in advance regarding the content of the comic media material. IEC was conducted at the beginning after the pre-test and at the end of the activity before the post-test. During 16 weeks the comic media can be read independently. How to take 52 eggs of Fe supplement, namely 1 item of Fe supplement every week and during menstruation consume 10 items at a dose of 1 x 1 tablet (assuming 7 days of menstrual duration is still consumed for 10 days) It is recommended that the right time to take iron supplements is at night to reduce the side effects of nausea. After 16 weeks, a hemoglobin check is done again as well as a post-test.

A sample of 126 young women aged 15 to 18 years was divided into 3 groups based on three selected state senior high schools in the District of Pesanggrahan, South Jakarta, Indonesia. The first group of 42 students became the intervention group that received $52 \mathrm{FE}$ supplements throughout the year and IEC about anemia through comic media. The administration was given for 16 weeks with details of once a week and for 10 days of menstruation. The second group of 42 students became the intervention group that only received $52 \mathrm{FE}$ supplements throughout the year without IEC about anemia. The third group became the control group that did not get both FE and IEC supplements on anemia. The inclusion criteria in determining the sample in this study were respondents who experienced regular menstrual cycles, were not taking Fe supplements in the last three months, we're willing to follow the research until it was finished and obtained permission from their parents. The exclusion criteria were respondents who could not represent the selected sample because they did not meet the requirements, namely: Respondents were in the process of changing schools, were undergoing treatment for infectious diseases or diseases that were contraindicated by giving supplementation of $\mathrm{Fe}$. The sampling technique used is probability sampling with the type of simple random sampling (Sastroasmoro \& Ismael, 2011).

This research was conducted in three selected state senior high schools in the District of Pesanggrahan, South Jakarta, Indonesia from March to October 2020. The instrument used in this study was comic media about the importance of consuming iron supplements for adolescents \& the impact of anemia on adolescents. This research has received ethical approval from the Ethics Commission for Health Research and Development of the Saint Carolus College of Health Sciences following the information worthy of ethics Number: 046/ KEPPKSTIKSC/V/2020. The analysis in this study used univariate, bivariate, and multivariate.

\section{Result}

Table 1

Differences in mean hemoglobin levels according to treatment and control groups before and after intervention $\dagger$

\begin{tabular}{lllll}
\hline \multirow{2}{*}{ Hemoglobin Level (g/dl) } & \multicolumn{3}{c}{ Group } & \multirow{2}{*}{ P-value } \\
\cline { 2 - 5 } & Fe Suppl.\& IEC & Fe Suppl. w/o IEC & Control & \\
\hline Before & $12,06 \pm 1,249$ & $12,55 \pm 1,566$ & $13,05 \pm 1,608$ & $0,012^{1}$ \\
After & $12,84 \pm 0,878$ & $13,20 \pm 1,071$ & $13,07 \pm 1,629$ & $0,414^{1}$ \\
\hline
\end{tabular}

$\dagger \chi \pm \mathrm{Sd},{ }^{1}$ Anova Test 
Before the intervention, the average hemoglobin level in the Fe supplementation and IEC group was 12.06 with a standard deviation of 1.249, in the Fe supplementation w/o IEC group the average hemoglobin level was 12.55 with a standard deviation of 1.566 and in the control group, the average of hemoglobin level was 13.05 with a standard deviation of 1.608. Based on the results of statistical tests with the Anova test, the $p$-value was obtained at 0.012, this indicates that at $5 \%$ alpha it can be concluded that there is a significant difference in the average of hemoglobin levels between the three groups at the time of the pre-test.

After the intervention, the average hemoglobin level in the Fe supplementation \& IEC group is 12.84 with a standard deviation of 0.878 , in the Fe supplementation w/o IEC group the average hemoglobin level is 13.20 with a standard deviation of 1.071, and in the control group, the average of hemoglobin level is 13.07 with a standard deviation of 1.629. Based on the results of statistical tests with the Anova test, the p-value was obtained at 0.414, this shows that at $5 \%$ alpha it can be concluded that there is no significant difference in the average hemoglobin levels between the three groups at the time of the post-test.

Table 2

The Difference from a difference in mean hemoglobin levels according to treatment and control groups before and after intervention $\dagger$

\begin{tabular}{|c|c|c|c|c|c|}
\hline \multirow{2}{*}{ Variable } & \multirow{2}{*}{ Group } & \multicolumn{2}{|c|}{ Average Value } & \multirow{2}{*}{$\begin{array}{l}\text { Diff. in } \\
\text { average }\end{array}$} & \multirow{2}{*}{ P-value } \\
\hline & & Before & After & & \\
\hline Hemoglobin & Fe Suppl. \& IEC & $12,06 \pm 1,249$ & $12,84 \pm 0,878$ & $0,78 \pm 0,52$ & $0,0005^{1}$ \\
\hline Level & Fe Suppl. w/o IEC & $12,55 \pm 1,566$ & $13,20 \pm 1,071$ & $0,65 \pm 0,66$ & $0,0005^{1}$ \\
\hline & Control & $13,05 \pm 1,608$ & $13,07 \pm 1,629$ & $0,02 \pm 0,29$ & 0,642 \\
\hline
\end{tabular}

$\dagger \chi \pm \mathrm{Sd},{ }^{1}$ Pair t-test

The difference in the mean and standard deviation of the variable hemoglobin levels from pre-test to post-test is shown in table 2. Hemoglobin levels in the Fe supplementation and IEC group from pre-test to post-test increased from 12.06 to 12.84 with a mean difference of 0.78 , p-value $<0.05(0.0005)$, this indicates that the $\mathrm{Fe}$ supplementation and IEC group increased significantly. In the group giving Fe without IEC, the hemoglobin level obtained from pre-test to post-test, increased from 12.55 to 13.20 with a mean difference of 0.65 , p-value $<0.05$ (0.00005) indicating that the Fe supplementation without IEC group, the improvement is significant. Hemoglobin levels in the control group from pre-test to post-test increased from 13.05 to 13.07 with a mean difference of 0.02 , pvalue> $0.05(0.642)$, indicating that the control group has no significant increase.

Table 3

The Results of the Final Modeling of Multivariate Linear Regression Analysis between Variables in the Fe Supplementation and IEC Group Based on the Increase in Hemoglobin Levels

\begin{tabular}{|c|c|c|c|c|c|}
\hline \multirow[t]{2}{*}{ Model } & \multicolumn{2}{|c|}{$\begin{array}{c}\text { Unstandardized } \\
\text { Coefficients }\end{array}$} & \multirow{2}{*}{$\begin{array}{c}\text { Standardized } \\
\text { Coefficients } \\
\text { Beta }\end{array}$} & \multirow[t]{2}{*}{$T$} & \multirow[t]{2}{*}{ P-value } \\
\hline & B & Std. Error & & & \\
\hline$\overline{\text { (Constant) }}$ & 3,921 & 0,703 & & 5.576 & 0.0005 \\
\hline Pocket Money & -0.296 & 0.129 & -0.252 & $-2,292$ & 0,028 \\
\hline Knowledge & $-0,828$ & 0,169 & $-0,521$ & $-4,914$ & 0,0005 \\
\hline Attitude & $-0,706$ & 0,193 & $-0,402$ & $-3,659$ & 0,001 \\
\hline Compliance & 0,444 & 0,134 & 0,367 & 3,318 & 0,002 \\
\hline Teacher Support & $-0,289$ & 0,127 & $-0,239$ & $-2,274$ & 0,029 \\
\hline
\end{tabular}

Dependent Variable $=$ Difference in Hb Level

$R$ Square $=0.609$ dan $R$ Adjusted $=0.555$

Based on the test results, the p-value of the mother's occupational variable is $>0.05$, therefore it must be excluded from the prediction model with consideration of adjusted $\mathrm{R}$ and value of $\mathrm{B}$. The test results after maternal employment are released in table 3. It turns out that there is no change in R-adjusted and $\Delta$ coeff $\mathrm{B}$ to more than $10 \%$, so the Mother Occupation variable leaves the multivariate model (Hastono, 2001). 


\section{Discussion}

Hemoglobin is an oxygen-carrying compound in red blood cells and provides the blood with red pigments. Hemoglobin can be measured chemically, i.e. $\mathrm{Hb} / 100 \mathrm{ml}$ of blood can be used as an index of the oxygen-carrying capacity of the blood. A low hemoglobin content indicates that a person has anemia (Supariasa, 2012).

Anemia in female teenagers occurs because adolescence is a time of growth that requires higher levels of nutrients, including iron. The effect of Fe supplementation on hemoglobin levels in the Fe supplementation and IEC through comic media group with a mean difference of 0.78 , p-value $<0.05(0.0005)$ indicates a significant increase, as well as in the Fe supplementation w/o IEC with a mean difference of 0.65 , p-value $<0.05$ (0.00005), indicating that the group had a significant increase. The difference in mean hemoglobin levels in the control group was $0.02, \mathrm{p}-$ value> 0.05 (0.642), indicating that the increase in the control group was not significant. Initial iron status can affect the iron metabolism system (Briawan et al., 2009). The results of this study are following the experimental study conducted by Briawan et al. (2007), regarding iron supplementation showing that changes in hemoglobin levels are only influenced by initial hemoglobin. Subjects who initially experience anemia can increase absorption by $40 \%$ faster than subjects without anemia (Brown, 2016).

The results of research by Leenstra et al. (2009), showed that weekly interventions for 12-an 18-year-old female teenagers in Kenya increased hemoglobin levels by $0.52(\mathrm{~g} / \mathrm{dl})$. Another study conducted by Bani et al. (2014), also showed two types of iron supplementation methods, weekly and during the menstrual period gave the same results to an increase in hemoglobin levels, $0.9 \pm 0.6(\mathrm{~g} / \mathrm{dl})$ in the weekly group and $1.1 \pm 0.7(\mathrm{~g} / \mathrm{dl})$ in the menstrual group. The success of the iron tablet supplementation program needs to be supported by an effective IEC strategy, so it is necessary to develop a model of iron supplementation for female teenagers in schools (Auerbach, 2009; Ruiz et al., 2006).

The Indicators of success (outcome) of the implementation program of Fe supplementation are reducing the prevalence of anemia in the target group. Indicators that can be used to assess the success of a program are an increase in hemoglobin levels and changes in anemia status (Briawan et al., 2009). Anemia in female teenagers in three state senior high schools in the District of Pesanggrahan, South Jakarta, Indonesia, is classified as mild and moderate anemia. The program in Vietnam was considered successful in reducing the prevalence of anemia because the supplementation program was added with the provision of worm medication interventions and followed by education to the target (Casey et al., 2009). The importance of education by teachers in monitoring iron consumption affects the program's success rate. Efforts to reduce the prevalence of anemia through high levels of compliance are influenced by good cooperation between various parties, including teachers and parents (Ramya, 2016).

The low level of supervision and motivation from consuming Fe at home makes the level of adherence low. The program of giving Fe in India in Risonar's research showed quite high compliance results, the $100 \%$ compliance value of Fe consumption was obtained (Risonar et al., 2008). Compliance was shown by consuming it directly with educational support and supervision from the teacher while at school and drinking Fe together on predetermined days.

The adherence of the Fe supplementation \& IEC group who received additional health education interventions through comics about the importance of consuming Fe supplements was known to be the highest because the information through these comics became the motivation for female teenagers in school to diligently consume Fe supplements. This is in line with research by Zavaleta et al. (2000), regarding the efficacy and acceptance of iron supplementation in school female teenagers in Peru who concluded that the level of adherence in consuming iron supplements was high after strong motivation at school. Adherence to taking iron supplementation or giving iron tablets greatly influenced changes in hemoglobin levels, where If the hemoglobin level is normal, the anemia status will also be normal, so that it can prevent and overcome iron deficiency anemia (Yuniarti \& Tunggal, 2015; Lindh et al., 2009).

The result of the multi regression analysis shows that the dominant variable is knowledge. Lestari et al. (2015), stated that respondents who consumed Fe tablets as a supplement during menstruation could not be separated from the information, knowledge, and awareness of the female teenagers themselves. Good knowledge affects the anemia status of female teenagers, this knowledge is not from scientific theory alone but from how to choose food ingredients to increase hemoglobin levels so that their anemia status is in the non-anemia category (Ahmady et al., 2017; Cakmak et al., 2008; Van Acht et al., 1992).

The knowledge of female teenagers about Fe tablets can be obtained through the provision of information and counseling on Fe tablets as nutritional supplementation for them which acts as a factor influencing knowledge about Fe tablets. So that the knowledge and awareness of female teenagers about Fe tablets will be better. Each individual 
to capture and process the information received is influenced by the acuity of the five senses so that it will produce a positive understanding (Notoatmodjo, 2012).

\section{Conclusion}

The prevalence of anemia in female teenager subjects has decreased after being given the intervention. The most dominant factor in increasing hemoglobin levels in this study was the knowledge of female teenagers in consuming dietary supplements. The program of supplementation with female teenagers for 16 weeks is still considered ineffective, even though the prevalence has decreased, but the adherence rate of consuming iron supplements is still low.

Suggestions for further research targets are to prioritize adolescent girls who experience anemia. Adherence to consuming Fe supplements is very low, knowledge and supporting factors from both parents and teachers are very important so that prevention practices against anemia can be carried out optimally and with this support can create positive attitudes for young girls to prevent anemia. Education and training for teachers by health workers related to the importance of the supplementation program and the management of the supplementation program for iron supplementation are very important.

\section{Ethical Clearance}

The Ethical Clearance is taken from the Ethics Commission of Health Research and Development Sint Carolus School of Health Sciences, Indonesia

\section{Source of Funding}

Ministry of Research and Technology/National Research and Innovation Agency Deputy for Research and Development Strengthening related to beginner lecturer research grants, 2020

\section{Acknowledgments}

We would like to thank the Ministry of Research and Technology/Deputy for Research and Development of the National Research and Development Agency regarding the research grant for beginner lecturers, 2020 who have been willing to fund this research.

\section{References}

Ahmady, A., Hapzah, H., \& Mariana, D. (2017). Penyuluhan gizi dan pemberian tablet besi terhadap pengetahuan dan kadar hemoglobin siswi sekolah menengah atas negeri di Mamuju. Jurnal Kesehatan Manarang, 2(1), 15-20.

Auerbach, A. D. (2009). Fanconi anemia and its diagnosis. Mutation Research/Fundamental and Molecular Mechanisms of Mutagenesis, 668(1-2), 4-10. https://doi.org/10.1016/j.mrfmmm.2009.01.013

Bani, S., Hassanpour-Siahestalkhi, A., Hassanpour, S., Mommad-Alizadeh-Charandabi, S., Mirghafourvand, M., \& Javadzadeh, Y. (2014). Comparison of two iron supplementation methods on Hemoglobin level and Menstrual Bleeding in Tabriz students. Iranian journal of pediatric hematology and oncology, 4(1), 11.

Briawan, D., Adriyani, A., \& Pusporini, P. (2009). Determinan keberhasilan program suplementasi zat besi pada siswi sekolah. Jurnal Gizi Klinik Indonesia, 6(2), 78-83.

Briawan, D., Setiawan, B., \& Marliyati, S. A. (2007). Efikasi suplemen besi-multivitamin untuk perbaikan status besi remaja wanita. Gizi Indonesia, 30(1).

Brown, J. E. (2016). Nutrition through the life cycle. Cengage Learning.

Cakmak, M., Cakmak, N., Cetemen, S., Tanriverdi, H., Enc, Y., Teskin, O., \& Kilic, I. D. (2008). The value of admission glycosylated hemoglobin level in patients with acute myocardial infarction. Canadian journal of cardiology, 24(5), 375-378. https://doi.org/10.1016/S0828-282X(08)70600-7

Campbell, D. T., \& Stanley, J. C. (2015). Experimental and quasi-experimental designs for research. Ravenio Books.

Casey, G. J., Phuc, T. Q., MacGregor, L., Montresor, A., Mihrshahi, S., Thach, T. D., ... \& Biggs, B. A. (2009). A free weekly iron-folic acid supplementation and regular deworming program is associated with improved hemoglobin and iron status indicators in Vietnamese women. BMC Public Health, 9(1), 261.

Hastono, S. P. (2001). Analisis data. Depok: Fakultas Kesehatan Masyarakat Universitas Indonesia. 
Leenstra, T., Kariuki, S. K., Kurtis, J. D., Oloo, A. J., Kager, P. A., \& Ter Kuile, F. O. (2009). The effect of weekly iron and vitamin A supplementation on hemoglobin levels and iron status in adolescent schoolgirls in western Kenya. European journal of clinical nutrition, 63(2), 173-182.

Lestari, P., Widardo, W., \& Mulyani, S. (2015). Pengetahuan berhubungan dengan konsumsi tablet Fe saat menstruasi pada remaja putri di SMAN 2 Banguntapan Bantul. Jurnal Ners dan Kebidanan Indonesia, 3(3), 145149.

Levy, A., Fraser, D., Katz, M., Mazor, M., \& Sheiner, E. (2005). Maternal anemia during pregnancy is an independent risk factor for low birthweight and preterm delivery. European Journal of Obstetrics \& Gynecology and Reproductive Biology, 122(2), 182-186. https://doi.org/10.1016/j.ejogrb.2005.02.015

Lindh, I., Blohm, F., Andersson-Ellström, A., \& Milsom, I. (2009). Contraceptive use and pregnancy outcome in three generations of Swedish female teenagers from the same urban population. Contraception, 80(2), 163-169. https://doi.org/10.1016/j.contraception.2009.01.019

Notoatmodjo, S. (2012). Promosi kesehatan dan perilaku kesehatan. Jakarta: rineka cipta, 45-62.

Ramya, M. R. (2016). Factors influencing weekly IFA supplementation programme (WIFS) among school children: where to focus our attention?.

Risonar, M. G. D., Tengco, L. W., Rayco-Solon, P., \& Solon, F. S. (2008). The effect of a school-based weekly iron supplementation delivery system among anemic schoolchildren in the Philippines. European journal of clinical nutrition, 62(8), 991-996.

Rollinson, D. (2011). Advances in Parasitology. Academic Press.

Ruiz, J. R., España-Romero, V., Ortega, F. B., Sjöström, M., Castillo, M. J., \& Gutierrez, A. (2006). Hand span influences optimal grip span in male and female teenagers. The Journal of hand surgery,31(8), 1367-1372. https://doi.org/10.1016/j.jhsa.2006.06.014

Sastroasmoro, S., \& Ismael, S. (2011). Dasar-dasar metodologi penelitian klinis. Jakarta: sagung seto, 55.

Simamora, D., Kartasurya, M. I., \& Pradigdo, S. F. (2018). Hubungan Asupan Energi, Makro Dan Mikronutrien Dengan Tekanan Darah Pada Lanjut Usia (Studi di Rumah Pelayanan Sosial Lanjut Usia Wening Wardoyo Ungaran, Tahun 2017). Jurnal Kesehatan Masyarakat (e-Journal), 6(1), 426-435.

Supariasa, I. (2012). Pendidikan \& konsultasi gizi. EGC.

Tefferi, A. (2003). Anemia in adults: a contemporary approach to diagnosis. In Mayo Clinic Proceedings (Vol. 78, No. 10, pp. 1274-1280). Elsevier. https://doi.org/10.4065/78.10.1274

Van Acht, M. J. J., Hermans, J., Boks, D. E. S., \& Leer, J. W. H. (1992). The prognostic value of hemoglobin and a decrease in hemoglobin during radiotherapy in laryngeal carcinoma. Radiotherapy and Oncology, 23(4), 229235. https://doi.org/10.1016/S0167-8140(92)80126-4

World Health Organization. (2011). Serum ferritin concentrations for the assessment of iron status and iron deficiency in populations (No. WHO/NMH/NHD/MNM/11.2). World Health Organization.

Yuniarti, R., \& Tunggal, T. (2015). Hubungan antara kepatuhan minum tablet Fe dengan kejadian anemia pada remaja putri di MA Darul Imad Kecamatan Tatah Makmur Kabupaten Banjar. Jurnal Publikasi Kesehatan Masyarakat Indonesia, 2(1), 31-36.

Zavaleta, N., Respicio, G., \& Garcia, T. (2000). Efficacy and acceptability of two iron supplementation schedules in adolescent school girls in Lima, Peru. The Journal of nutrition, 130(2), 462S-464S. 